\title{
Employee Empowerment, Psycological Contract, Employee Engagement di Universitas di Indonesia
}

\author{
Mohammad Benny Alexandri ${ }^{1}$, Nenden Kostini ${ }^{2}$, Erna Maulina ${ }^{3}$ \\ Fakultas Ilmu Sosial dan Ilmu Politik, Universitas Padjadjaran \\ mohammad.benny@unpad.ac.id¹; nenden.kostini@unpad.ac.id²; erna.maulina@unpad.ac.id³
}

\begin{abstract}
Some of the problems faced by lecturers in higher education are the lack of time for research because of teaching. Another problem is: a career as a lecturer is an endpoint or basis for a career elsewhere? The question is that the position of lecturer or being a Professor is still something interesting, prestigious, or not? Padjadjaran University is the number 6 Best University in Indonesia in QS World version in 2018. The number of lectuJrers is 1780 Lecturers. The purpose of this research is to find out Employee Empowerment, Psychological Contract and Employee Engagement at Padjadjaran University. The unit of analysis is 65 Permanent Lecturers at Padjadjaran University. The results of this study found that the effect of Employee Empowerment, Psycological Contract on Employee Engagement was only 15\%. This indicates that the Padjadjaran University Lecturer does not yet have a strong Empowerment and Psychological Contract to produce a strong attachment to the University.
\end{abstract}

Keywords: Employee Empowerment, Psycological Contract, Employee Engagement, Padjadjaran University, Indonesia

\section{Pendahuluan}

Sebagian besar dosen yang bekerja di Perguruan Tinggi Negeri (PTN) di Indonesia adalah Pegawai Negeri Sipil (PNS), sehingga secara administratif tidak tersedia kontrak kerja berbasis kinerja (performance based contract). Pengaturannya di tuangkan dalam bentuk Keputusan Menteri Penetapan Aparatur Negara dengan tugas dosen lebih dari 30 butir, dan setiap jenjang jabatan akademik ada ketetapannya. Kinerja dosen dinilai menggunakan instrument DP3 yang lebih mengukur kinerja integritas dan loyalitas, tetapi bukan untuk mengujur kinerja akademik.

Dosen baik yang aktif meneliti, menulis atau tidak tetap mendapatkan pengharagaan yang relatif sama dengan implikasi dapat menyebabkan keengganan berkarya. Belum pernah dijumpai ada dosen di PTN di Indonesia yang dihentikan karena tidak pernah meneliti atau tidak pernah publikasi internasional. Sebagai penggantinya adalah adalah pembinaan oleh dosen senior kepada dosen yunior. Pembinaan ini melekat otomatis sebagai tugas senior dan pejabat di atasnya.

Beberapa permasalahan yang dihadapi oleh dosen di perguruan tinggi antara lain tidak adanya waktu untuk penelitian yang terdesak oleh pengajaran. Permasalahan lain adalah: apakah karir menjadi dosen merupakan endpoint atau dasar untuk karir di tempat lain? Lebih ekstrim lagi ada dosen yang universitas negeri yang pindah ke luarnegeri yang menunjukkan gejala braindrain. Menjadi pertanyaan, apakah jabatan dosen atau menjadi seorang Guru Besar merupakan sesuatu yang menarik, prestisius, atau tidak? (Prof. Dr. Laksono Trisnantoro, 2008)

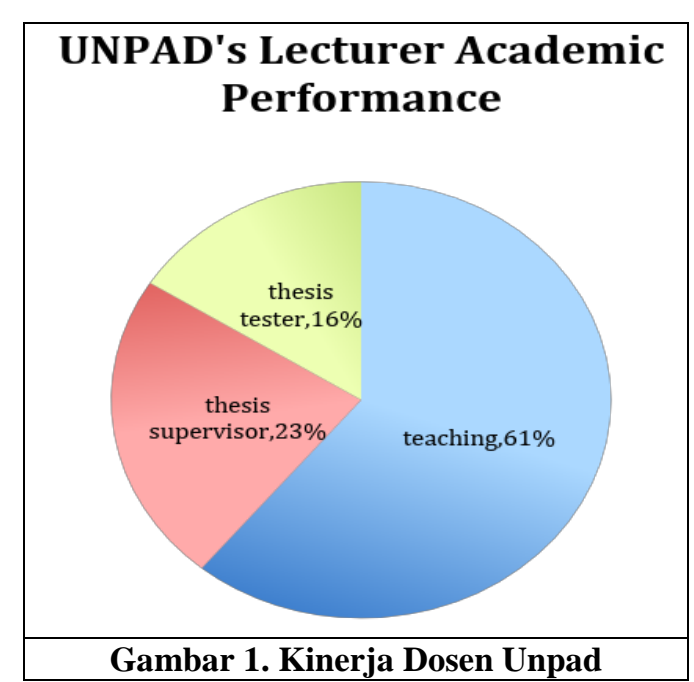

Di sisi lain, rekruitmen dosen di berbagai universitas di Indonesia sebagian besar dari usia muda sehingga membutuhkan waktu yang panjang untuk menjadi dosen yang matang. Ketika dalam perjalanan karir sebagai dosen ada masalah maka akan menyebabkan adanya sekelompok dosen yang kurang produktif. Sementara itu untuk menambah langsung dosen, seperti yang bisa dilakukan di perguruan tinggi di luar negeri.

Kemampuan akademik universitas negeri lemah karena masalah rekrutmen dan pengembangan dosen yang masih belum sesuai standar perguruan tinggi internasional. Oleh karena itu manajemen universitas 
negeri harus berubah. Jika tidak maka univesitas asing akan masuk ke Indonesia dan/atau kita akan terus kalah bersaing. Kita harus berani mulai berubah, yang dapat diawali dari universitas dan fakultas yang berani melakukan perubahan (Laksono Trisnantoro). Sebetulnya SDM yang ada di universitas sangat luar biasa. Hal ini diindikasikan dengan banyaknya dosen yang menjadi konsultan dan komisaris perusahaan lokal, nasional, ataupun internasional. Akan tetapi situasi dan manajemen di lembaga universitas sendiri malah tidak dapat dikelola dengan baik.(Cipto Subroto)

Berdasarkan data Profil UNPAD 2016, jumlah seluruh dosen UNPAD PNS adalah sebanyak 1780 dosen. Jumlah ini merupakan gabungan dari 16 fakultas.

Jumlah dosen UNPAD ini saat ini berkembang, terutama setelah UNPAD menjadi PTN-BH. UNPAD juga menerima dosen UNPAD non PNS. Jumlah dosen nya disesuaikan dengan kebutuhan dari masing-masing fakultas di lingkungan UNPAD.

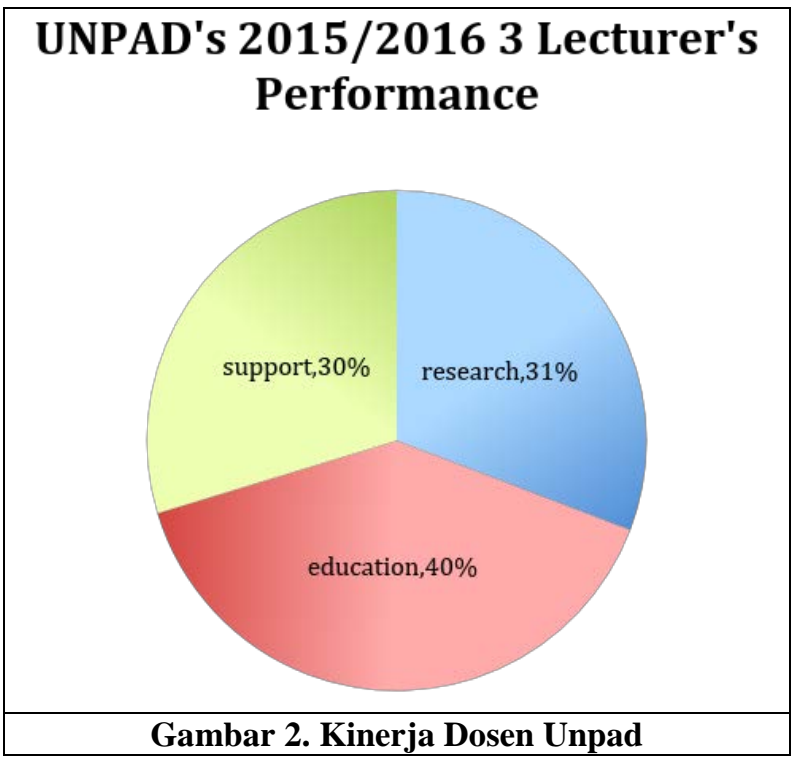

Kepuasan kerja adalah suatu teori atau konsep praktis yang sangat penting, Karena merupakan dampak atau hasil dari keefektivan performance dan kesuksesan dalam bekerja.

Kepuasan kerja yang rendah pada organisasi adalah rangkaian dari (1) menurunnya pelaksanaan tugas, (2) meningkatnya absensi, dan (3) penurunan moral organisasi. Sedangkan pada tingkat individu, ketidakpuasan kerja , berkaitan dengan (1) keinginan yang besar untuk keluar dari kerja, (2) meningkatnya stress kerja, dan (3) munculnya berbagai masalah psikologis dan fisik.

\section{Studi Literatur}

\section{Kontrak Psikologis (Psycological Contract)}

Apakah sebenarnya kontrak psikologis? Istilah kontrak psikologis (psycological contract) berbeda dengan kontrak kerja. Robinson dan Rousseau (2000) menyatakan bahwa kontrak kerja secara umum mengacu pada dokumen tertulis yang mengatur hak dan kewajiban seorang karyawan dan tunduk pada peraturan perusahaan. sedangkan kontrak psikologis merupakan sebuah kontrak yang bersifat implisit antara seorang individu dan organisasinya yang menspesifikkan pada apa yang masing-masing harapkan satu sama lain untuk saling memberi dan menerima dalam suatu hubungan kerja.

Rousseau (2000) dalam Conway dan Briner (2005) mengemukakan bahwa kontrak psikologis merupakan keyakinan individu, yang dibentuk dari organisasi dimana keyakinan tersebut mengacu pada persetujuan antara individu dan organisasinya.

Menurut De Vos (2002), kontrak psikologis mencakup aspek hubungan kerja baik yang dilakukan perusahaan kepada karyawan maupun karyawan kepada perusahaan. Organisasi berjanji kepada karyawannya dalam hal (a) Pengembangan karir, (b) Penawaran Pekerjaan, (c) Lingkungan social, (d) Keuangan dan (e) Keseimbangan dengan pribadi karyawan. Sedangkan karyawan berjanji kepada organisasi dalam bentuk (a) Usaha dan performance kinerja, (b) Keluwesan, (c) Loyalitas, (d) Berperilaku lebih baik dan (e) Ketersediaan. Sehingga dapat disimpulkan bahwa aspek kontrak psikologis mengacu pada timbal balik antara organisasi dengan karyawan nya. Karyawan berkeyakinan mengenai hal-hal yang dijanjikan organisasi baik dalam hal keadilan, pemberian gaji, kejelasan status kerja, kesejahteraan pegawai dan peningkatan karir yang jelas. Organisasi juga mengharapkan karyawan yang dapat selalu memberikan kontribusinya bagi kemajuan perusahaan.

Menurut De Vos (2002), kontrak psikologis mencakup aspek hubungan kerja baik yang dilakukan perusahaan kepada karyawan maupun karyawan kepada perusahaan. Organisasi berjanji kepada karyawannya dalam hal (a) Pengembangan karir, (b) Penawaran Pekerjaan, (c) Lingkungan social, (d) Keuangan dan (e) Keseimbangan dengan pribadi karyawan. Sedangkan karyawan berjanji kepada organisasi dalam bentuk (a) Usaha dan performance kinerja, (b) Keluwesan, (c) Loyalitas, (d) Berperilaku lebih baik dan (e) Ketersediaan. Sehingga dapat disimpulkan bahwa aspek kontrak psikologis mengacu pada timbal balik antara organisasi dengan karyawan nya. Karyawan berkeyakinan mengenai hal-hal yang dijanjikan organisasi baik dalam hal keadilan, pemberian gaji, kejelasan status kerja, kesejahteraan pegawai dan peningkatan karir yang jelas. Organisasi juga mengharapkan karyawan yang dapat selalu memberikan 
kontribusinya bagi kemajuan perusahaan. Tujuan penelitian ini adalah : (1) Pemberdayaan, Kontrak Psikologis dan Keterikatan Karyawan, dosen Universitas Padjadjaran. (2) Unit analisis adalah dosen PNS yang bekerja di Universitas Padjadjaran, Bandung - Jawa Barat.

\section{Pemberdayaan (Employee Empowerment)}

Pemakaian istilah pemberdayaan berawal dari lingkungan politik yang bertujuan untuk memperkuat pengaruh politik, umumnya di antara orang-orang yang tidak terlibat dalam pengambilan keputusan. Lalu, penggunaan istilah ini kemudian berkembang ke dalam lingkungan organisasi, dimana pengertian pemberdayaan tidak mengarah pada aspek kepribadian namun lebih menggambarkan keyakinan individu mengenai hubungannya dengan lingkungan (Spreitzer, 1997).

Menurut Stewart (1998) employee empowerment berarti memampukan dan memberi kesempatan kepada karyawan untuk merencanakan, melaksanakan rencana, dan mengendalikan rencana pekerjaan yang menjadi tanggung jawabnya atau tanggung jawab kelompoknya. Sedangkan Luthans (1998) men-definisikan empowerment sebagai wewenang dalam membuat keputusan dalam sebuah area pekerjaan tanpa membutuhkan persetujuan dari orang lain. Empowerment dapat dibagi menjadi dua perspektif umum yaitu: relational perspective (organizational empowerment) dan psychological perspective (psychological empowerment). Relational empowerment meyakini bahwa empowerment tercipta ketika tingkatan yang lebih tinggi dalam hirarki perusahaan membagi kekuasaannya kepada tingkatan yang lebih rendah. Sedangkan psychological perspective fokus pada persepsi empowerment yang dimiliki karyawan. Psychological empowerment merupakan variabel yang merefleksikan atau mencerminkan tingkatan empowerment yang dirasa-kan karyawan. (Spreitzer, 1997; Conger dan Kanungo, 1988).

\section{Keterikatan Karyawan (Employee Engagement)}

Employee engagement merupakan rasa keterikatan secara emosional dengan pekerjaan dan organisasi, termotivasi dan mampu memberikan kemampuan terbaik mereka untuk membantu sukses dari serangkaian manfaat nyata bagi organisasi dan individu, (McLeod, 2009).

Perrin's Global Workforce Study (2003) mendefinisikan keterikatan karyawan sebagai kesediaan dan kemampuan individu karyawan untuk mewujudkan keberhasilan organisasi dalam mencapai tujuan, dengan cara memberikan kontribusi pemikiran dan upaya berkelanjutan. Berdasarkan studi dinyatakan bahwa keterikatan individu karyawan dengan organisasi dibentuk oleh keterikatan emosional dan faktor rasional yang berhubungan dengan pengalaman kerja dan lingkungan kerja.

Engagement didefinisikan sebagai sikap yang positif, penuh makna, dan motivasi, yang dikarakteristikkan dengan vigor, dedication, dan absorption (Schaufeli, 2002 dalam Breso, Schaufeli, \& Salanova, 2010). Vigor dikarakteristikkan dengan tingkat energi yang tinggi, resiliensi, keinginan untuk berusaha, dan tidak menyerah dalam menghadapi tantangan. Dedication ditandai dengan merasa bernilai, antusias, inspirasi, berharga dan menantang. Absorption ditandai dengan konsentrasi penuh terhadap suatu tugas.

\section{Metode Penelitian}

Penelitian ini menggunakan metode deskriptif, verifikatif dan eksplanatori, yaitu suatu metode yang dipergunakan untuk memperoleh gambaran secara konkrit dan akurat dari ciri-ciri variabel yang diteliti. Dengan menggunakan metode ini akan diuraikan secara terperinci dan jelas perilaku dari setiap variabel yang diteliti. Penelitian ini dikategorikan deskriptif karena menggambarkan atau memotret variabel-variabel yang diteliti. Sementara sifat penelitian verifikatif pada dasarnya ingin menguji kebenaran suatu hipotesis yang dilaksanakan melalui pengumpulan data di lapangan menggunakan metode survey.

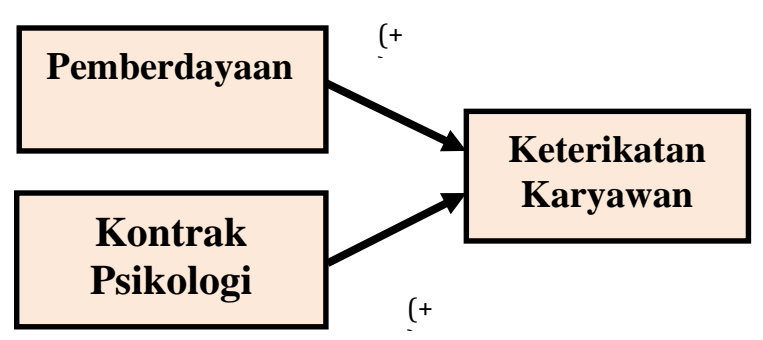

Gambar 1.

Keterkaitan Pemberdayaan dan Kontrak Psikologi dengan

Hipotesis

1. Terdapat Pengaruh Positif Antara Pemberdayaan Pada Keterikatan Karyawan Pada Dosen Universitas Padjadjaran.

2. Terdapat Pengaruh Positif Antara Kotrak Psikologi Dengan Keterikatan Karyawan Pada Dosen Universitas Padjadjaran.

3. Terdapat Pengaruh Positif Antara Pemberdayaan Dan Kotrak Psikologi Dengan Keterikatan Karyawan Pada Dosen Universitas Padjadjaran. 


\section{Diskusi}

\section{Pengaruh Pemberdayaan terhadap Keterikatan Karyawan}

Hasil dari Pengaruh variable Pemberdayaan terhadap Keterikatan Karyawan dapat disampaikan sebagai berikut :

\begin{tabular}{|l|r|r|r|r|r|}
\multicolumn{7}{|c|}{ De scriptive Statistics } \\
\hline & N & Minimum & Maximum & Mean & Std. Deviation \\
\hline X1 & 65 & 2.00 & 11.00 & 6.5846 & 2.33112 \\
Valid N (listwise) & 65 & & & & \\
\hline
\end{tabular}

Jumlah data yang digunakan sebanyak 65 responden yang terdiri dari dosen-dosen di 16 Fakultas di Unpad. Jumlah jawaban minimum untuk pertanyaan yang diajukan dengan metode likert adalah sebesar 2 . Sedangkan nilai maksimum adalah 11. Rata-rata jawaban reponden adalah 6,58 yang artinya mayoritas responden berada pada jawaban "setuju" pada pertanyaan-pertanyaan yang diajukan oleh kuesioner.

Adapun jumlah standar deviasi atau tingkat penyimpangan yang terjadi adalah sebesar 2,3.

Kontrak psikologis merupakan kontrak yang tidak tertulis, kontrak ini hanya ada di dalam psikologis karyawan. Tingkat kontrak psikologis yang tinggi dari karyawan, akan meningkatkan kinerja karyawan. Hal ini disebabkan karena karyawan merasa bangga dapat bekerja di perusahaan yang telah memenuhi harapan dan keinginannya (Ivancevich, 2006: 166).

Hasil analisis data menunjukkan bahwa pada saat dilakukan penelitian, sampel penelitian memiliki kontrak psikologis terhadap perusahaan dalam kategori rendah. Terujinya hipotesis ini menunjukkan bahwa kontrak psikologis dapat menentukan kinerja karyawan. Karyawan yang memiliki kontrak psikologis dengan perusahaan yang besar di dalam dirinya akan merasa bangga dapat bekerja di perusahaan yang telah memenuhi harapan dan keinginannya sehingga karyawan akan menunjukkan kecenderungan kinerja yang baik.

Pengaruh Pemberdayaan dan Kontrak Psikologis terhadap Keterikatan Karyawan.

\begin{tabular}{|l|r|r|r|r|r|}
\hline \multicolumn{1}{|c|}{ De scriptive Statistics } \\
\hline Y & N & Minimum & Maximum & Mean & Std. Deviation \\
Valid N (listwise) & 65 & 1.00 & 5.00 & 2.7800 & 1.15166 \\
\hline
\end{tabular}

Dalam table di atas digambarkan bahwa :

1. Secara rata-rata responden menjawab sebear 2,8 atau jawaban rata-rata tidak setuju atau netral.

2. Jawaban maksimum adalah 5 , artinya rata-rata menyatakan setuju terhadap pengaruh antara $\mathrm{x} 1$ dan x2 terhadap y

3. Penyimpangan yang terjadi adalah $1,15 \%$.

\begin{tabular}{|c|c|c|c|c|}
\hline \multicolumn{5}{|c|}{ Correlations } \\
\hline & & $\mathrm{X} 1$ & $\times 2$ & $\mathrm{Y}$ \\
\hline \multirow[t]{3}{*}{$\mathrm{X} 1$} & Pearson Correlation & 1 & -.169 & $.350^{\star \star}$ \\
\hline & Sig. (2-tailed) & & .180 & .004 \\
\hline & $\mathrm{N}$ & 65 & 65 & 65 \\
\hline \multirow[t]{3}{*}{$\mathrm{X} 2$} & Pearson Correlation & -.169 & 1 & .178 \\
\hline & Sig. (2-tailed) & .180 & & .156 \\
\hline & $\mathrm{N}$ & 65 & 65 & 65 \\
\hline \multirow[t]{3}{*}{$\mathrm{Y}$} & Pearson Correlation & $.350^{\star \star}$ & .178 & 1 \\
\hline & Sig. (2-tailed) & .004 & .156 & \\
\hline & $\mathrm{N}$ & 65 & 65 & 65 \\
\hline
\end{tabular}

**. Correlation is significant at the 0.01 level (2-tailed).

\begin{tabular}{|c|c|c|c|c|}
\hline \multicolumn{5}{|c|}{ Model Summary } \\
\hline Model & $\mathrm{R}$ & R Square & $\begin{array}{l}\text { Adjusted } \\
\text { R Square }\end{array}$ & $\begin{array}{l}\text { Std. Error of } \\
\text { the Estimate }\end{array}$ \\
\hline 1 & $.424^{\mathrm{a}}$ & .180 & .153 & 1.05964 \\
\hline
\end{tabular}

a. Predictors: (Constant), X1, X2

Dari Table Di Atas Tergambar Bahwa :

1. Pengaruh Antara Pemberdayaan Dan Kontrak Psikologis Pada Keterikatan Karyawan Adalah 0,153 Atau15\% Saja.

2. Nilai Pengaruh Ini Sedang.

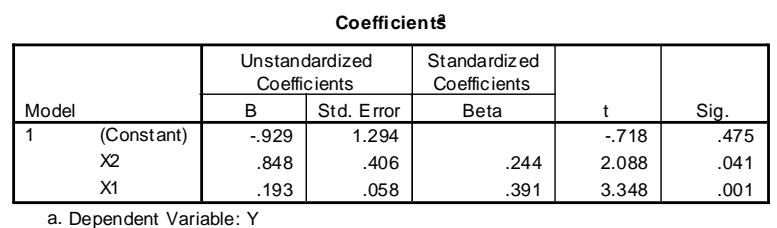

model 2 dalam penelitian ini adalah :

$\mathrm{Y}=0,929+0,849 \mathrm{X} 1+0,193 \mathrm{X} 2+\mathrm{e}$

Hal ini menunjukkan bahwa : Semakin besar nilai X1 dan X2 akan mengakibatkan semakin kuatnya keterikatan karyawan (dosen) pada lembaga, yaitu Universitas Padjadjaran.

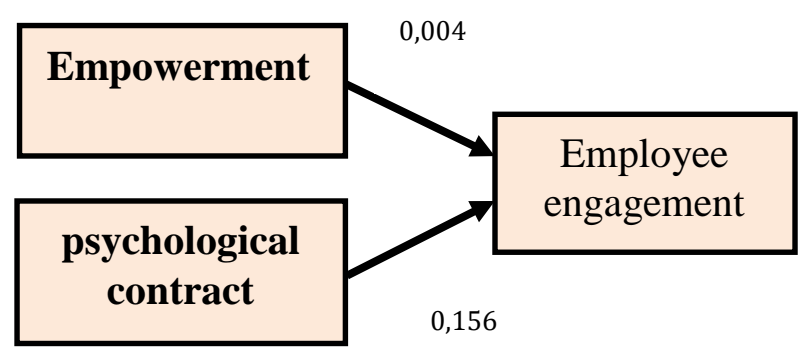

\section{Kesimpulan}

1. Hasil penelitian ini menemukan bahwa terdapat pengaruh positif antara pemberdayaan dan keterikatan karyawan secara positif pada dosen UNiversitas Padjadjaran. 
2. Hasil penelitian ini menemukan terdapat pengaruh poitif antara kontrak Psikologis dan Keterikatan Karyawan.

3. Terdapat pengaruh positif dan signifikan kedua variable independent pada variable dependent Dosen Universitas Padjadjaran adapun nilai pengaruh adalah sebesar 15\%.

\section{Daftar Pustaka}

Arikunto, Suharsimi. 2006. Prosedur Penelitian Suatu Pendekatan Praktik. Jakarta : Rineka Cipta.

Bass, B.M\&Avolio, 1990, “The Implications of Transaksional and Transformational”,Team and Organization Development, 4, p.231-273

Conway dan Briner. (2005). Understanding Psychological Contracts at Work. New York: Oxford University.

David E. Guest, Neil Conway. (2002). Communicating the psychological contract : an employer perspective. Human Resource Management Journal. Vol. 12, No. 2, 22-38.

Ketut IR Sudiardhita, Saparuddin Mukhtar, Budi Hartono, Herlitah, Tuty Sariwulan, Sri Indah Nikensari,(2018) The Effect Of Compensation, Motivation Of Employee And Work Satisfaction To Employee Performance Pt. Bank Xyz (Persero) Tbk, Academy of Strategic Management Journal Volume 17, Issue 4, 2018

Profil Universitas Padjadjaran 2016

Robinson, D., Perryman, S., and Hayday, S. (2004), The Drivers of Employee Engagement,

Robinson, S.R., \& Morrison, E.W. (2000). The Development Of Psychological Contract Breach and Violation: A Longitudinal Study. Journal of Organizational Behaviour. 21, pp. 525-546.

Rousseau, D. M. Dan Parks, J. M. (1993). The Contracts of Individuals and Organizations. Research in Organizational Behavior.

Rousseau, D.M. (1989), 'Psychological and Implied Contracts in Organizations,' Employee

Rousseau. (2000). Psychological Contract Inventory Technical Report. USA: Camegie Mellon University.

Schaufeli, W.B., Salanova, M., Gonzales-Roma, V., and Bakker, A.B. (2002), 'The Measurement of Engagement and Burnout: A Two Sample Confirmatory Factor Analytic Approach,' Journal of Happiness Studies, 3, 71-92
Spreitzer, G. M. et al. (1997). A Dimensional Analysis Of The Relationship Between Psychological Empowerment and Effectiveness, Satisfaction, and Strain. Journal Of Management. 23 (5), pp. 679-704.

Spreitzer, G.M. (1995), "Psychological empowerment in the workplace: dimensions, measurement, and validation”, Academy of Management Journal, Vol. 38 No. 5, pp. 1442-65.

Spreitzer, G.M. (1996), "Social structural characteristics of psychological empowerment”, Academy of Management Journal, Vol. 39 No. 2, pp. 483504.

Sugiyono. (2005). Metode Penelitian Kualitatif. Bandung: Alfabeta.

Suharsimi Arikunto, (2006). Prosedur Penelitian (Suatu Pendekatan Praktik). Jakarta: PT. Rineka Cipta.

Susilo Toto Raharjo, Durrotun Nafisah (2006), Analisis Pengaruh Gaya Kepemimpinan Terhadap Kepuasan Kerja, Komitmen Organisasi Dan Kinerja Karyawan (Studi Empiris Pada Departemen Agama Kabupaten Kendal Dan Departemen Agama Kota Semarang)

Suzyanty Mohd Shokory, Nur Riza Mohd Suradi (2018) Transformational Leadership And Its Impact On Extra-Role Performance Of Project Team Members: The Mediating Role Of Work Engagement, Academy Of Strategic Management Journal Volume 17, Issue 4, 2018

Thoha, M. 2001, Kepemimpinan Dalam Manajemen, Suatu Pendekatan Perilaku, Rajawali Press , Jakarta

Veithzal Rivai, 2004, Kepemimpinan dan Perilaku Organisasi, Edisi Kedua PT Rajagrafinda Persada, Jakarta.

Veithzal Rivai. 2004. Manajemen Sumber Daya Manusia Untuk Perusahaan. Cetakan Pertama. Jakarta: PT. Raja Grafindo.Yogyakarta 